\title{
ARE PLATINUM NANOPARTICLES SAFE TO HUMAN HEALTH?
}

\author{
Ewelina Czubacka, Sławomir Czerczak \\ Nofer Institute of Occupational Medicine, Łódź, Poland \\ Department of Chemical Safety
}

\begin{abstract}
Platinum nanoparticles (PtNPs) have been widely used not only in industry, but above all in medicine and diagnostics. However, there are disturbing reports related to the toxic effects of nanoplatinum, which is the main reason why the authors of this study have decided to review and analyze literature data related to its toxicity and impact on human health. While PtNPs may be absorbed by the respiratory and digestive tract, and can penetrate through the epidermis, there is no evidence concerning their absorption through the skin. Platinum nanoparticles accumulate mainly in the liver and spleen although they also reach other internal organs, such as lungs, kidneys or heart. Toxicokinetics of platinum nanoparticles depends strongly on the particle size. Only few studies regarding platinum nanoparticles toxicity have been conducted. Animals intratracheally exposed to platinum nanoparticles have demonstrated an increased level of proinflammatory cytokines in bronchoalveolar lavage which confirms inflammatory response in the lungs. Oral administration of PtNPs can cause inflammatory response and induce oxidative stress. Nanoplatinum has been found to induce hepatotoxicity and nephrotoxicity via the intravenous route. It can cause DNA damage and cellular apoptosis without significant cytotoxicity. There are no research studies on its carcinogenicity. Fetal or maternal toxicity has not been observed, but an increased mortality and a decreased growth of the offspring have been demonstrated. Platinum nanoparticles may permeate the skin barrier but there is no evidence for their absorption. Due to the insufficient number of tests that have been carried out to date, it is not possible to clearly determine the occupational exposure limit value; however, caution is recommended to employees exposed to their effects. Med Pr. 2019;70(4):487-95
\end{abstract}

Key words: occupational health, nanoparticles, toxicology, platinum, health effects, occupational exposure

Corresponding author: Ewelina Czubacka, Nofer Institute of Occupational Medicine, Department of Chemical Safety, św. Teresy 8, 91-348 Łódź, Poland, e-mail: ewelina.czubacka@imp.lodz.pl

Received: December 4, 2018, accepted: January 24, 2019

\section{INTRODUCTION}

Nanotechnology has been one of the fastest developing fields in the last 2 decades. The increase in human exposure to nanoparticles has raised concerns regarding their health and safety profiles.

Platinum metal is generally well known for its great ability of catalyzing partial oxidation, hydrogenation and dehydrogenation (due to a large surface area), which is crucial for many industrial processes [1], and it exhibits some specific properties such as a large surface area and good resistance to corrosion and chemical attacks [2].

Platinum nanoparticles are widely used not only in many different technologies, consumer products (cosmetics, supplements, food additives) [3,4], electrocatalysis, data storage systems, new electronic devices, elec- trochemical biosensors, chemisensors, fluorescent and refractometric sensors [5] but also in medicine, diagnostics and treatment, due to their lower cytotoxicity resulting from chemical stability and resistance to ionization, as compared with other metal nanoparticles [6,7].

Platinum nanoparticles (PtNPs) have found a number of biomedical applications, e.g., in diagnostic mediators, medical implants, drug delivery vehicles and photothermal therapy compounds $[8,9]$, as well as in enhanced radiosensitization [10], detection of cancer cells [11], bond strength between tooth structures [12] and bacterio-toxic effects [1].

Drugs based on platinum have been in clinical use since 1971 (cisplatin which entered clinical trials and was approved for use by the U.S. Food and Drug Administration in 1978) and are employed in the treat-

Funding: prepared within a statutory project of the Nofer Institute of Occupational Medicine (project No. IMP 24.17 entitled "Spatial distribution of the occurrence and exposure of employees to the most common occupational factors with carcinogenic or mutagenic effects in Poland," project manager: Katarzyna Konieczko, M.Sc.). 
ment of numerous solid malignancies (breast, ovarian, head, neck, colorectal, bladder, neuroblastoma) $[13,14]$. There are also promising studies on the use of platinum nanoparticles in the treatment of Parkinson's disease [15]. Quite interesting is the fact that inhalation of platinum nanoparticles may provide smokers with a therapeutic benefit, acting as an improved lung antioxidant defense against cigarette smoke $[15,16]$. There are also data demonstrating that PtNPs can act as a scavenger of reactive oxygen species $[17,18]$.

The aim of this review is to provide a comprehensive evaluation of the current knowledge regarding the bio-toxic impacts of the platinum nanoparticles exposure on human health, in terms of both in vivo and in vitro experiments, which are not fully understood at present. An increased use of PtNPs for many different purposes implies an increased risk of human exposure, and it is the main reason why these nanoparticles have been found among the interests of industrial hygienists. Despite the broad use of platinum nanoparticles, there are limited data on their toxicity and the possible size-dependent effects.

Platinum is not on the list of hazardous substances set out in Annex VI to Regulation (EC) No. 1272/2008 of the European Parliament and of the Council on classification, labelling and packaging of substances and mixtures, amending and repealing Directive 67/548/ EEC and 1999/45/EC, and amending Regulation (EC) No. 1907/2006 [19].

\section{METHODS}

The literature review was made on the basis of the Internet databases of peer-reviewed scientific journals, including EBSCO Discovery Service (EDS), MedLine and PubMed, using the following keywords: "platinum nanoparticles application," "toxicity," "toxicokinetics," "exposure," "occupational exposure limits" and "available Internet data." In the preparation of this study, works published until 2018 were considered. English was the main language in which the articles were reviewed. The presented paper includes all the articles connected with the influence of exposure to platinum nanoparticles on health. A summary of the studies included in the review is presented in Table 1.

\section{RESULTS}

Acute and sub-chronic toxicity studies Intratracheal instillation

Platinum nanoparticles are reported to cause inflammatory response in lungs.

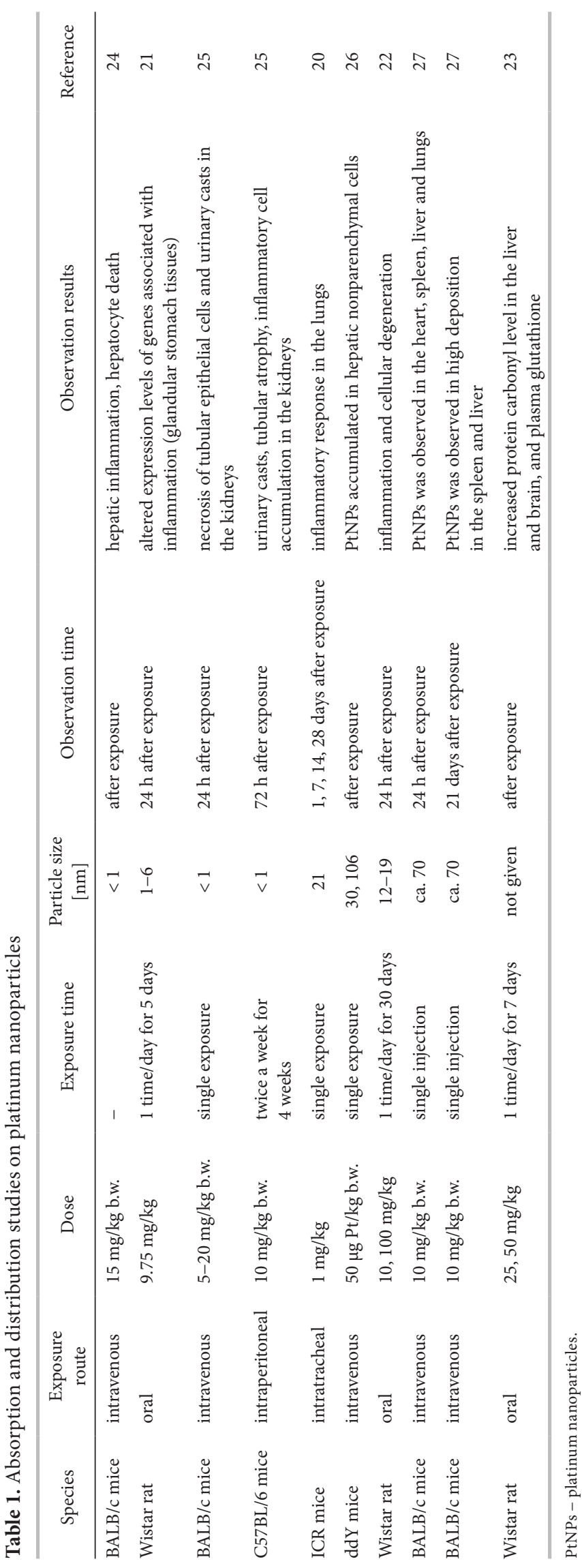


In one of the studies, ICR mice were exposed to a single intratracheal instillation of platinum nanoparticles $(21 \mathrm{~nm}, 1 \mathrm{mg} / \mathrm{kg})$. The authors observed increased levels of IL-1, TNF- $\alpha$, IL-6 (pro-inflammatory cytokines), IL-2 (TH0 cytokine), IL-12 (TH1-type cytokine), IL-4 and IL-5 (TH2-type cytokines) in broncho-alveolar lavage fluid (BALF). On the 28th day after the exposure, the induction of TH2-cytokines was higher than that of TH1-type cytokines. In BALF, increased levels of TGF- $\beta$ and IgE in the serum were also observed, providing strong evidence that platinum nanoparticles induce inflammatory response in mice [20].

\section{Oral administration}

Platinum nanoparticles, after oral administration, can cause inflammatory response and oxidative stress.

Male Wistar rats were orally exposed (via gavage) to PtNPs (1-6 nm) in a dose of $9.75 \mathrm{mg} / \mathrm{kg} /$ day for 5 consecutive days. The animals were sacrificed $24 \mathrm{~h}$ after the last exposure. The examined tissues, i.e., those of the glandular stomach, showed altered expression levels of genes associated with inflammation. The authors concluded that the orally administered platinum nanoparticles did not have a marked effect on the systemic gene expression levels (except on a small number of expressed genes in rat tissues), including peripheral tissues indirectly exposed to nanoobjects given orally [21].

Adeyemi et al. exposed Wistar rats to PtNPs via the oral route [22]. The animals received a daily dose of the studied nanoparticles $(10,50$ or $100 \mathrm{mg} / \mathrm{kg})$ for $30 \mathrm{con}$ secutive days. The authors observed that platinum nanoparticles caused significant alterations to organ weights. An increase in the total protein level in tissues, a decrease in albumin, and alterations of the serum urea levels and creatinine were observed. Interesting is the fact that the activities of alkaline phosphatase and aspartate transaminase were reduced while the level of alanine aminotranferase was raised in the liver (both in tissues and serum). This study demonstrated that platinum nanoparticles caused morphological lesions, including inflammation (an increase in the total protein concentration in the heart, kidney and liver) and cellular degeneration [22].

In another study, Adeyemi et al. administered PtNPs orally to male Wistar rats (25 and $50 \mathrm{mg} / \mathrm{kg}$ ) in daily doses for 7 consecutive days [23]. After the exposure, increased protein carbonyl levels in the liver, brain and plasma glutathione were observed. The authors concluded that platinum nanoparticles might cause oxida- tive stress in rat plasma at the highest dose. Lipid peroxidation in the rat brain or plasma was not observed [23].

Intravenous administration

Intravenous administration demonstrated that nanoplatinum accumulates in the heart, spleen, liver and lungs while the highest amount was observed 21 days after the exposure in the liver and spleen. However, PtNPs induced hepatotoxicity and nephrotoxicity [24-27].

Yamagishi et al. studied toxic effects of sub-nanosized platinum particles $(<1 \mathrm{~nm})$ [25]. For this purpose, the authors administered a single dose of $15 \mathrm{mg} / \mathrm{kg}$ b.w. of PtNPs intravenously to BALB/c mice. Acute hepatic injury with vacuole degeneration was revealed by histological analysis. Exposure to PtNPs in doses over $15 \mathrm{mg} / \mathrm{kg}$ resulted in a significant elevation of the serum alanine aminotransferase (ALT) and aspartate aminotranserase (AST) levels, and IL-6. The levels of AST and ALT increased 3-24 h after the exposure to a dose of $20 \mathrm{mg} / \mathrm{kg}$. These results suggest that sub-nanosized platinum nanoparticles induced inflammation and hepatocyte death. The animals exposed to $15 \mathrm{~nm}$ PtNPs showed no significant changes in the AST, ALT and IL-6 levels. The authors concluded that the biological effect of platinum nanoparticles strongly depended on their size [24].

In another study conducted by Yamagishi et al., $\mathrm{BALB} / \mathrm{c}$ mice were exposed to platinum nanoparticles with a particle size $<1$ and $<8 \mathrm{~nm}$, in a single dose of $5-20 \mathrm{mg} / \mathrm{kg}$. The histological analysis revealed necrosis of tubular epithelial cells and urinary casts in the kidneys. There were no changes in the lungs, spleen and heart. The injurious effects were reduced by increasing the particle size [25].

Katsumi et al. exposed ddY mice to a single intravenous administration of platinum nanoparticles (30 and $106 \mathrm{~nm}$ ). The authors observed that PtNPs accumulated in hepatic nonparenchymal cells. Smaller platinum nanoparticles inhibited the increase in hepatic injury markers (ALT, AST) to a greater extent than the larger ones. It is concluded that platinum nanoparticles may be used to prevent hepatic ischemia/reperfusion injury [26].

In another study, BALB/c mice were exposed to a single intravenous injection (into tail vein). Short-term biodistribution studies were performed at a concentration of $10 \mathrm{mg} \mathrm{Pt} / \mathrm{kg}$ b.w., and after $24 \mathrm{~h}$ the organs were harvested. The authors did not detect any platinum nanoparticles in the plasma of the mice, while PtNPs were observed in all tested organs (the liver, spleen, kidney and lungs). In long-term biodistribution, the mice were in- 
jected with doses of 5, 10, 15 and $20 \mathrm{mg} \mathrm{Pt} / \mathrm{kg}$ b.w. The organs were collected after 21 days of the exposure. The authors analyzed the fraction of the injected Pt that was retained after $24 \mathrm{~h}$ and 3 weeks in the mice exposed to a dose of $10 \mathrm{mg} / \mathrm{kg}$ b.w. Platinum was not detected in the plasma after $24 \mathrm{~h}$ of the exposure, which indicated that PtNPs had been either excreted form the system or deposited in tissues/organs. The biggest depositions of the studied nanoparticles were observed in the liver and spleen. The test results (AST, ALT, bilirubin, albumin, blood urea nitrogen, creatinine and sodium) showed no abnormal levels in comparison to the control group [27].

\section{Intraperitoneal administration}

Intraperitoneal administration is strongly determined by the nanoparticle size, with bigger nanoparticles inducing nephrotoxicity.

In one study, Yamagishi et al. exposed intraperitoneally C57BL/6 mice to platinum particles $(8 \mathrm{~nm},<1 \mathrm{~nm})$ twice a week for 4 weeks, in a dose of $10 \mathrm{mg} / \mathrm{kg}$. The authors observed (in the case of smaller particles) urinary casts, tubular atrophy and inflammatory cell accumulation on the basis of the histological analysis performed afterwards. In the case of $8 \mathrm{~nm}$ platinum nanoparticles, nephrotoxic effects were not observed [25].

\section{Dermal exposure}

Platinum nanoparticles penetrate through the skin barrier, while their absorption is not observed.

One of the first experimental studies concerning platinum skin absorption was carried out by Taubler, in which rabbits and guinea pigs were exposed to repeated dermal application of platinum sulfate. The author did not observe any trace amounts of platinum in the urine or serum [28]. However, Roshchin et al. found platinum in the urine, blood and internal organs of animals treated with ammonium chloroplatinate after dermal exposure [29].

Konieczny et al. in their studies focused on the effects of polyvinylpyrrolidone-coated platinum nanoparticles (5.8 and $57 \mathrm{~nm}$ ) and demonstrated that PtNPs triggered toxic effects on primary keratinocytes, decreasing cell metabolism [30]. It is worth to mention that these effects have no influence on migration or cell viability. Smaller nanoparticles exhibit more deleterious effects on DNA stability and higher caspases activation than the bigger ones [30].

Franken et al. conducted studies on the human abdominal full thickness skin obtained after surgical abdominoplasty [31]. The skin was exposed to a mixture of rhodium and platinum for $6,8,10,12,14$ and $24 \mathrm{~h}$. The results demonstrated that the $\mathrm{Pt}$ and $\mathrm{Rh}$ mixture might permeate through an intact skin, with permeation increasing cumulatively over time [31].

Platinum nanoparticles $(5.8 \pm 0.9 \mathrm{~nm})$ were applied to the outer surface of the skin (the human abdominal full thickness skin obtained as a surgical waste) for $24 \mathrm{~h}$. The results of this study revealed that PtNPs might penetrate through the skin barrier and even a minor injury to the skin barrier could significantly increase metal penetration [32].

\section{Carcinogenicity}

The authors of this article have not found any data confirming the carcinogenic effect of platinum nanoparticles in human or animal studies. However, there are reports suggesting that PtNPs delay the growth of lung cancer in treated SCID mice [33].

\section{Mutagenicity and genotoxicity}

On the basis on in vitro studies, it was demonstrated that platinum nanoparticles induced DNA damage and apoptosis, and could be used as anticancer agents. However, PtNPs did not cause significant cytotoxicity.

Pelka et al., on the basis of their study, demonstrated that platinum nanoparticles caused DNA strand breaks in human colon carcinoma cells (HT29) [34]. The authors did not observe toxic effects, and they concluded that the platinum ions from nanoparticles might be used in anticancer therapies with a similar strategy to cisplatin.

The results of another study, conducted by Asharani et al., suggest p53 activation in Pt-NP-treated cells due to genotoxic stress, with the subsequent activation of p21 leading to a proliferating cell nuclear antigen-mediated growth arrest and apoptosis [11]. The researchers recommended the development of platinum nanoparticles based anticancer agents by appropriate surface modifications to augment their innate anticancer activity.

Gehrke et al. described the DNA-damaging properties of platinum nanoparticles as related to the association of Pt with DNA [3]. The authors concluded that DNA strand breaks mediated by metallic PtNPs were caused by the platinum ions forming during the incubation of cells. The study was carried out on human colon carcinoma cells.

Exploring the genotoxicity of PtNPs (5 and $50 \mathrm{~nm}$ ) on human bronchial epithelial cells was the aim of the study conducted by Lebedová et al. [35]. The authors concluded that the studied nanoobjects showed a size- 
dependent effect, i.e., $50 \mathrm{~nm}$ platinum nanoparticles caused a small increase in DNA damage in comparison to the $5 \mathrm{~nm}$-sized ones.

Platinum nanoparticles obtained with the green synthesis method can be exploited for the administration of drugs via conjugation with metabolites. In in $v i$ tro studies on human breast adenocarcinoma cell line (MCF-7), PtNPs induced apoptosis through G0/G1 cell cycle arrest. The authors concluded that DNA damage resulted from indexed oxidative pressure [2].

Nejdl et al. inhibited the activity of Taq DNA polymerase and DNA structure damage [36]. The authors concluded that this effect, together with the transition of platinum nanoparticles into platinum ions $\left(\mathrm{Pt}^{2+}\right)$, caused mutagenicity and an increased DNA damage in comparison to cisplatin. Cytotoxicity of PtNPs may increase by the encapsulation in liposomes.

Human bronchial epithelial cells were exposed to platinum nanoparticles ( 5 and $50 \mathrm{~nm}$ ). On the basis of a comet assay and micronucleus test, the authors concluded that only $50 \mathrm{~nm}$ particles caused a slight increase in DNA damage [35].

\section{Embryotoxicity, teratogenicity and reprotoxicity}

Nanoplatinum has not been observed to cause fetal or maternal toxicity, but an increased mortality and a decreased growth of the offspring have been demonstrated, along with mitochondria degeneration in brain tissue.

In one of the studies, ICR mice were exposed to a single oral dose of platinum nanoparticles $(20 \mathrm{~nm})$ during premating, gestation and lactation periods $(0.25$, 0.5 and $1 \mathrm{mg} / \mathrm{kg}$, respectively). The authors observed an increase in offspring mortality and a decreased infant growth rate during the lactation period. Biochemical, histopathological and mortality changes, stillbirth or deformity were not observed [37].

Prasek et al. in their research investigated the effects of platinum nanoparticles on the chicken embryo model [38]. For this purpose, the embryos were exposed to injected in ovo PtNPs solutions $(1-20 \mu \mathrm{g} / \mathrm{ml})$. The test results indicated that platinum nanoparticles did not affect the growth and development of the embryos. Further studies revealed no significant changes in the number of cells in the brain cortex but analyses of the brain tissue ultrastructure revealed mitochondria degradation [38].

\section{In vitro studies}

Kachi et al. treated THP-1 human monocytic cells for $24 \mathrm{~h}$ with colloidal platinum nanoparticles [39]. On the basis of the obtained results, the authors concluded that PtNPs did not mitigate mitochondrial or oxidative stress.

Human bronchial epithelium (BEAS-2B) and human lung alveolar type II epithelioid cells (A549) were treated with platinum nanoparticles $\left(25 \mathrm{~nm}, 8.13 \mathrm{mg} / \mathrm{m}^{3}\right)$. After 24 h, A549 cell resulted in a loss of viability. The no-observed adverse effect level (NOAEL) was $0.1 \mu \mathrm{g} / \mathrm{ml}$ $\left(0.031 \mu \mathrm{g} / \mathrm{cm}^{2}\right)$ and the lowest observed adverse effect level (LOAEL) was $1 \mu \mathrm{g} / \mathrm{ml}\left(0.31 \mu \mathrm{g} / \mathrm{cm}^{2}\right)$; thus, BEAS-2B was considered as not sensitive to platinum nanoparticles. The authors observed a remarkable increase in IL-8 due to exposure in both cell lines, which was dependent on the time of exposure which, in turn, was related to the deposited mass [40].

$\mathrm{Li}$ et al. investigated the impact of $1.7 \mathrm{~nm}$ PtNPs on Deinococcus radiodurans. The authors showed that concentrations of ca. $4700 \mathrm{PtNPs} /$ cell did not have any major effects on bacterial growth under normal growth conditions. Interesting is the fact that platinum nanoparticles slightly, but reproducibly, increased cell death after the exposure to gamma rays. The authors claimed that such an amplification effect was due to the confined production of reactive oxygen species in nano-volumes around nanoparticles which favored the induction of complex damage in biomolecules [41].

A HepG2 liver model was used to characterize the toxicological potential of platinum nanoparticles in in vitro studies. The authors observed that high doses of PtNPs (70 nm, citrate coated) induced HepG2 cytotoxicyty. Lower concentrations did not induce direct toxicity, but the combined presence of intracellular stress, active inflammatory responses with upregulated signal transduction might have influence on long-term health hazards [42].

Buchtelova et al., in their in vitro studies on 3 different types of malignant cell lines (GI-ME-N - neuroblastoma, MDA-MB-231 - breast, LNCaP - prostate), demonstrated that the diameter had a crucial role in cytotoxicity [13]. The smallest particles (PVP-capped PtNPs) were observed to be the most cytotoxic (ca. $10 \mathrm{~nm}$, ca. $14 \mathrm{~nm},>20 \mathrm{~nm})$.

\section{Irritation and sensitization}

The authors of this article have not found any data confirming the irritating and/or sensitizing effects of platinum nanoparticles in human or animal studies. However, it is well known that soluble platinum compounds have shown evidence of eye irritation in animal tests. Some of them have been found to be severely irritating 
or even corrosive [43]. Skin irritation has also been observed, ranging from mild to severe or corrosive $[43,44]$.

According to a report posted on the European Chemicals Agency (ECHA) website [45], platinum demonstrated diffuse corneal opacity, and iris inflammation and moderate conjunctival irritation were observed during a $72 \mathrm{~h}$ observation period, based on in vivo tests (New Zealand white rabbits). Conjunctival redness did not reverse during this period. No eye irritation category is required based on the EU CLP criteria (EC 1272/2008).

The minority of notifiers on the ECHA website classified platinum as a skin sensitizer but there are no data confirming the sensitization effect of platinum nanoparticles.

Table 2. Hygienic standards for metallic platinum, binding in Poland and other countries [48,49]

\begin{tabular}{|c|c|}
\hline Country & $\begin{array}{c}\text { TWA } \\
{\left[\mathrm{mg} / \mathrm{m}^{3}\right]}\end{array}$ \\
\hline Australia & 1 \\
\hline Austria & 1 (inhalable aerosol) \\
\hline Belgium & 1 \\
\hline Canada & 1 \\
\hline Denmark & 1 \\
\hline Finland & 1 \\
\hline France & 1 \\
\hline Germany & 1 (inhalable aerosol) \\
\hline Hungary & 1 \\
\hline Ireland & 1 \\
\hline Italy & 1 \\
\hline Latvia & 1 \\
\hline New Zealand & 1 \\
\hline Poland & 1 \\
\hline Singapore & 1 \\
\hline South Korea & 1 \\
\hline Spain & 1 \\
\hline Sweden & 1 \\
\hline Switzerland & 1 (inhalable aerosol) \\
\hline The Netherlands & 1 \\
\hline Turkey & 1 \\
\hline USA - ACGIH & 1 \\
\hline USA - NIOSH & 1 \\
\hline United Kingdom & 5 \\
\hline
\end{tabular}

ACGIH - American Conference of Governmental Industrial Hygienists, TWA - time-weighted average, NIOSH - National Institute for Occupational Safety and Health.

\section{Occupational Exposure Limits in Poland and in the world}

A review by Kiilunen et al. demonstrated that the air levels of platinum in the working environment are usually lower than $2 \mu \mathrm{g} / \mathrm{m}^{3}$, but in a platinum refinery they were reported to reach up to $2200 \mu \mathrm{g} / \mathrm{m}^{3}$ [46].

Commission Directive 91/322/EEC sets an indicative limit value for the occupational exposure to platinum metal at $1 \mathrm{mg} / \mathrm{m}^{3}$ [47]. The occupational exposure limit (OEL) values have been divided into 2 standards. Table 2 presents the OEL values for platinum metal in global terms, indicating that only the United Kingdom has adopted a higher value of $5 \mathrm{mg} / \mathrm{m}^{3}$ as the total inhalable dust. For the soluble platinum compounds, such as $\mathrm{Pt}$, which are classified as sensitizing in most countries, the value is $2 \mu \mathrm{g} / \mathrm{m}^{3}$ [48]. Asthma and upper respiratory tract irritation were assumed as the critical effects.

The Scientific Committee on Occupational Exposure Limits (SCOEL) has found that the available data are too uncertain to determine the OEL value for platinum [49]. On the basis of the platinum nanoparticles toxicity data, it is not possible to determine the dose-response relationship in humans. Also, the results of animal toxicity studies of PtNPs do not allow the results extrapolation appropriate for the determination of the OEL value [48].

Taking into account the specific mechanism of toxicity of nanoobjects, the authors take a position that the data published so far are not sufficient to determine the precise value of the platinum nanoparticles occupational exposure level in its pure form.

\section{CONCLUSIONS}

Platinum nanoparticles have been widely used not only in industry, but above all in medicine and diagnostics. However, there are disturbing reports related to the toxic effects of nanoplatinum, which is the main reason why the authors of this study decided to review and analyze literature data related to its toxicity and impact on human health.

While PtNPs may be absorbed by the respiratory and digestive tract, and can penetrate through the epidermis, there is no evidence concerning their absorption through the skin. Platinum nanoparticles accumulate mainly in the liver and spleen although they also reach other internal organs, such as lungs, kidneys or heart. Toxicokinetics of platinum nanoparticles depends strongly on the particle size. 
Only few studies regarding platinum nanoparticles toxicity have been conducted. Animals intratracheally exposed to platinum nanoparticles demonstrated an increased level of proinflammatory cytokines in bronchoalveolar lavage which confirms inflammatory response in the lungs. Oral administration of PtNPs can cause inflammatory response and induce oxidative stress. Nanoplatinum has been found to induce hepatotoxicity and nephrotoxicity via the intravenous route. It can cause DNA damage and cellular apoptosis without significant cytotoxicity. There are no research studies on its carcinogenicity. Fetal or maternal toxicity has not been observed, but an increased mortality and a decreased growth of the offspring have been demonstrated.

Unfortunately, the collected data are not sufficient to determine the exact risk, and there is a huge need to conduct short- and long-term experimental studies on the basis of which the OEL value could be determined. Due to their small size and properties, PtNPs are capable of overcoming biological barriers and reaching specific organs to induce a toxic effect. Therefore, caution is recommended to employees exposed to platinum nanoparticles in their working environment.

On the basis of the platinum nanoparticles toxicity data, it is not possible to determine the dose-response relationship in animals and, therefore, no results extrapolation, appropriate for the determination of the OEL value, can be performed.

\section{REFERENCES}

1. Gopal J, Hasan N, Manikandan M, Wu H. Bacterial toxicity/compatibility of platinum nanospheres, nanocuboids and nanoflowers. Sci Rep. 2013;3:1260, https://doi.org/10.1038/ srep01260.

2. Şahin B, Aygün A, Gündüz H, Şahin K, Demir E, Akocak S, et al. Cytotoxic effects of platinum nanoparticles obtained from pomegranate extract by the green synthesis method on the MCF-7 cell line. Coll Surf B Biointerfaces. 2018; 163:119-24, https://doi.org/10.1016/j.colsurfb.2017.12.042.

3. Gehrke H, Pelka J, Hartinger CG, Blank H, Bleimund F, Schneider R, et al. Platinum nanoparticles and their cellular uptake and DNA platination at non-cytotoxic concentrations. Arch Toxicol. 2011;85:799-812, https://doi. org/10.1007/s00204-010-0636-3.

4. Horie M, Kato H, Endoh S, Fujita K, Nishio K, Komaba LK, et al. Evaluation of cellular influences of platinum nanoparticles by stable medium dispersion. Metallomics. 2011;3: 1244-52, https://doi.org/10.1039/c1mt00060h.
5. Obreja L, Pricop D, Foca N, Melnig V. Alcoholic reduction platinum nanoparticles synthesis by sonochemical method. Mater Plast. 2008;47:42-7.

6. Elder A, Yang H, Gwiazda R, Teng X, Thurston S, He H, et al. Testing nanomaterials of unknown toxicity: An example based on platinum nanoparticles of different shapes. Adv Mater. 2007;19:3124-29, https://doi.org/10.1002/adma.200701962.

7. Kawasaki H, Yonezawa T, Watanabe T, Arakawa R. Platinum nanoflowers for surface-assisted laser desorption/ionization mass spectrometry of biomolecules. J Phys Chem C. 2007;111:16279-83, https://doi.org/10.1021/jp075159d.

8. Johnstone TC, Suntharalingam K, Lippard SJ. The next generation of platinum drugs: targeted Pt(II) agents, nanoparticle delivery, and Pt(IV) prodrugs. Chem Rev. 2016;116(5): 3436-86, https://doi.org/10.1021/acs.chemrev.5b00597.

9. Wang Z, Chen L, Huang C, Huang Y, Jia N. Albumin-mediated platinum nanocrystals for in vivo enhanced computed tomography imaging. J Mater Chem B. 2017;5(19): 3498-510, https://doi.org/10.1039/C7TB00561J.

10. Porcel E, Liehn S, Remita H, Usami N, Kobayashi K, Furusawa Y., et al. Platinum nanoparticles: a promising material for future cancer therapy? Nanotechnology. 2010;21:85103, https://doi.org/10.1088/0957-4484/21/8/085103.

11. Asharani PV, Xinyi NG, Hande PM, Valiyaveettil S. DNA damage and p53-mediated growth arrest in human cells treated with platinum nanoparticles. Nanomedicine. 2010; 5:51-64, https://doi.org/10.2217/nnm.09.85.

12. Hoshika S, Nagano F, Tanaka T, Ikeda T, Wada T, Asakura K, et al. Effect of application time of colloidal platinum nanoparticles on the microtensile bond strength to dentin. Dental Mater J. 2010;29:682-9, https://doi.org/10.4012/dmj. 2009-125.

13. Buchtelova H, Dostalova S, Michalek P, Krizkova S, Strmiska V, Kopel P, et al. Size-related cytotoxicological aspects of polyvinylpyrrolidone-capped platinum nanoparticles. Food Chem Toxicol. 2017;105:337-46, https://doi.org/10. 1016/j.fct.2017.04.043.

14. Boulikas T, Pantos A, Bellis E, Christofis P. Designing platinum compounds in cancer: Structures and mechanisms. Cancer Ther. 2007;5:537-83.

15. Nellore J, Pauline C, Amarnath K. Bacopa monnieri phytochemicals mediated synthesis of platinum nanoparticles and its neurorescue effect on 1-methyl 4-phenyl-1,2,3,6-tetrahydropyridine-induced experimental Parkinsonism in zebrafish. J Neurodegener Dis. 2013;2013:972391, https:// doi.org/10.1155/2013/972391.

16. Onizawa S, Aoshiba K, Kajita M, Miyamoto Y, Nagai A. Platinum nanoparticles antioxidants inhibit pulmonary inflammation in mice exposed to cigarette smoke. Pulmon 
Pharm Therap. 2009;22:340-9, https://doi.org/10.1016/ j.pupt.2008.12.015.

17. Nakanishi H, Hamasaki T, Kinjo T, Yan H, Nakamichi N, Kabayama S, et al. Low concentration platinum nanoparticles effectively scavenge reactive oxygen species in rat skeletal L6 cells. Nano Biomed Eng. 2013;5(2):76-85, https:// doi.org/10.5101/nbe.v5i2.p76-85.

18. Gatto F, Moglianetti M, Pompa PP, Bardi G. Platinum nanoparticles decrease reactive oxygen species and modulate gene expression without alteration of immune responses in THP-1 monocytes. Nanomaterials. 2018;8(6):392, https://doi.org/10.3390/nano8060392.

19. Regulation (EC) No 1272/2008 of the European Parliament and of the Council on classification, labelling and packaging of substances and mixtures, amending and repealing Directive 67/548/EWG and 1999/45/EC and amending Regulation (EC) No 1907/2006. OJ EU L353/1

20. Park E-J, Kim H, Kim Y, Park K. Intratracheal instillation of platinum nanoparticles may induce inflammatory reponse in mice. Arch Pharm Res. 2010;33(5):727-35, https://doi. org/10.1007/s12272-010-0512-y.

21. Katao K, Honma R, Kato S, Watanabe S, Imai J-I. Influence of platinum nanoparticles orally administered to rats evaluated by systemic gene expression profiling. Exp Anim. 2011;60(1):33-45.

22. Adeyemi OS, Sulaiman FA, Akanji MA, Oloyede HOB, Sulaiman AA, Olatunde A, et al. Biochemical and morphological changes in rats exposed to platinum nanoparticles. Comp Clin Pathol. 2016;25:855-64, https://doi.org/10.10 07/s00580-016-2274-5.

23. Adeyemi OS, Olajide IO, Adeyanju AA, Awakan OJ, Otohinoyi DA. Modulation of rat plasma kynurenine level by platinum nanoparticles and likely association with oxidative stress. Bioint Res Appl Chem. 2018;8(4):3364-7.

24. Yamagishi Y, Watari A, Hayata Y, Li X, Kondoh M, Tsutsumi Y, et al. Hepatotoxicity of sub-nanosized platinum particles in mice. Pharmazie. 2013;68:178-82, https://doi. org/10.1691/ph.2013.2141.

25. Yamagishi Y, Watari A, Hayata Y, Li X, Kondoh M, Yoshioka $\mathrm{Y}$, et al. Acute and chronic nephrotoxicity of platinum nanoparticles in mice. Nanoscale Res Lett. 2013;8:395, https://doi.org/10.1186/1556-276X-8-395.

26. Katsumi H, Fukui K, Sato K, Maruyama S, Yamashita S, Mizumoto E, et al. Pharmacokinetics and preventive effects of platinum nanoparticles as reactive oxygen species scavengers on hepatic ischemia/reperfusion injury in mice. Metallomics. 2014;6:1050-6, https://doi.org/10.1039/c4mt 00018h.

27. Brown AL, Kai MP, DuRoss A, Sahay G, Sun C. Biodistribution and toxicity of micellar platinum nanoparticles in mice via intravenous administration. Nanomaterials. 2018;8:410, https://doi.org/10.3390/nano8060410.

28. United States Environmental Protection Agency [Internet]. North Carolina: The Agency; 1977 [cited 2018 Oct 19]. Environmental Health Effects Research Series. Allergic response to platinum and palladium complexes. Determination of no-effect level. Available from: https://nepis.epa.gov/ Exe/ZyPDF.cgi/91013EMY.PDF?Dockey=91013EMY.PDF.

29. Roshchin AV, Veselov VG, Panova AI. Industrial toxicology of metals of metals of the platinum group. J Hyg Epidemiol Microbiol Immunol. 1984;28:17-24.

30. Konieczny P, Goralczyk AG, Szmyd R, Skalniak L, Koziel J, Larese FF, et al. Effects triggered by platinum nanoparticles on primary keratinocytes. Int J Nanomed. 2013;8:3963-75, https://doi.org/10.2147/IJN.S49612.

31. Franken A, Eloff FC, Du Plessis J, Badenhorst CJ, Jordaan A, $\mathrm{Du}$ Plessis JL. In vitro permeation of platinum and rhodium through Caucasian skin. Toxicol In Vitro. 2014;28: 1396-401, https://doi.org/10.1016/j.tiv.2014.07.007.

32. Mauro M, Crosera M, Bianco C, Adami G, Montini T, Fornasiero $\mathrm{P}$, et al. Permeation of platinum and rhodium nanoparticles through intact and damaged human skin. J Nanopart Res. 2015;17:253, https://doi.org/10.1007/ s11051-015-3052-z.

33. Bendale Y, Bendale V, Natu R, Paul S. In vitro and in vivo anticancer activity of bio-Pt NPs. J Pharm. 2016;19(2):11421, https://doi.org/10.3831/KPI.2016.19.012.

34. Pelka J, Gehrke H, Esselen M, Türk M, Crone M, Bräse S, et al. Cellular uptake of platinum nanoparticles in human colon carcinoma cells and their impact on cellular redox systems and DNA integrity. Chem Res Toxicol. 2009; 22:649-59, https://doi.org/10.1021/tx800354g.

35. Lebedová J, Hedberg YS, Wallinder IO, Karlsson HL. Size-dependent genotoxicity of silver, gold and platinum nanoparticles studied using the mini-gel comet assay and micronucleus scoring with flow cytometry. Mutagenesis. 2018;33:77-85, https://doi.org/10.1093/mutage/gex027.

36. Nejdl L, Kudr J, Moulick A, Hegerova D, Ruttkay-Nedecky B, Gumulec J, et al. Platinum nanoparticles induce damage to DNA and inhibit DNA replication. PLoS ONE. 2017;12(7):e0180798, https://doi.org/10.1371/journal.pone. 0180798

37. Park EJ, Kim H, Kim Y, Park K. Effects of platinum nanoparticles on the postnatal development of mouse pups by maternal exposure. Environ Health Toxicol. 2010;25(4):27986.

38. Prasek M, Sawosz E, Jaworski S, Grodzik M, Ostaszewska T, Kamaszewski M, et al. Influence of nanoparticles of platinum on chicken embryo development and brain morphology. Nanoscale Res Lett. 2013;8:251, https://doi.org/ 10.1186/1556-276X-8-251. 
39. Kachi H, Noda M, Wataha JC, Nakaoki Y, Sano H. Colloidal platinum nanoparticles increase mitochondrial stress induced by resin composite components. J Biomed Mater Res B App Biomater. 2011;69B(2)193-8, https://doi. org/10.1002/jbm.b.31750.

40. Diabaté S, Weiss C, Mülhopt S, Paur H-R, Niedetzky V, Seipenbusch M. Biological effects in human lung cells exposed to platinum nanoparticles aerosol. European Aerosol Conference; 2009 Sept 11; Karlsruhe, Germany.

41. Li S, Porcel E, Remita H, Marco S, Réfrégiers M, Dutertre $\mathrm{M}$, et al. Platinum nanoparticles an exquisite tool to overcome radioresistance. Cancer Nanotechnol. 2017;8:4, https://doi.org/10.1186/s12645-017-0028-y.

42. Labrador-Rached CJ, Browning RT, Braydich-Stolle LK, Comfort KK. Toxicological implications of platinum nanoparticle exposure: Stimulation of intracellular stress, inflammatory response and akt signaling in vitro. J Toxicol. 2018:1367801, https://doi.org/10.1155/2018/1367801.

43. International Programme on Chemical Safety [Internet]. Geneva: World Health Organization; 1991 [cited 2018 Oct 19]. Platinum. Environmental Health Criteria. Available from: http://www.inchem.org/documents/ehc/ehc/ehc125.htm.

44. Campbell KI, George EL, Hall LL, Stara JF. Dermal irritancy of metal compounds. Studies with palladium, platinum, lead, and manganese compounds. Arch Environ Health. 1975;30:168-70, https://doi.org/10.1080/00039896.1975.10 666669.

45. European Chemicals Agency [Internet]. Helsinki: The Agency; 2018 [cited 2018 Oct 29]. Registration dossier. Available from: https://echa.europa.eu/registration-dossier/-/registered-dossier/19458.

46. Kiilunen M, Aitio A, Santonen T. Platinum. In: Nordberg GF, Fowler BA, Nordberg M, editors. Handbook on the Toxicology of Metals. 4th ed. Vol. 2. Amsterdam: Academic Press; 2015, p. 1125-41, https://doi.org/10.1016/B978-0444-59453-2.00050-0.

47. Commission Directive of 29 May 1991 on establishing indicative limit values by implementing Council Directive $80 / 1107 / \mathrm{EEC}$ on the protection of workers from the risks related to exposure to chemical, physical and biological agents at work (91/322/EEC). Off J Eur Union L 27/115

48. Nordberg GF, Fowler BA. Risk Assessment for Human Metal Exposures. Mode of Action and Kinetic Approaches. 1st ed. London, San Diego, Cambridge, Oxford: Academic Press; 2018, p. 301304.

49. Recommendation from Scientific Committee on Occupational Exposure Limits for Platinum and Platinum compounds, SCOEL/SUM/150. 2011.

This work is available in Open Access model and licensed under a Creative Commons Attribution-NonCommercial 3.0 Poland License - http://creativecommons.org/licenses/by-nc/3.0/pl/deed.en. 